\title{
Study on College Counsellors' Ideological and Political Education Work on Post-00 College Students in the Internet + Era
}

\author{
Dongyu Wang \\ School of education, Shandong Women's University, Jinan, Shandong, 250300, China \\ Corresponding author.Email:2683488023@qq.com
}

\begin{abstract} political education.

\section{Introduction}

Since the year 2018, post-00 college students have become the protagonists of university campuses, and stepped on the stage of history. As can be seen, $98 \%$ of the newly admitted college students in 2019 are post-00s. Are they able to take responsibilities for the development of the society in the future? What are the characteristics of them? How should college counselors carry out ideological and political work on them, and be their good organizers, implementers, and guides[1]?The author of this paper intends to talk about some innovative strategies of ideological and political education based on his own work experience and the analysis of post-00s' characteristics from different aspects.
\end{abstract}

Youth is the future of the country and the hope of the nation. Nowadays, post- 00 college students have become the protagonists of university campuses. Their new ideas, characteristics, and behaviors have brought new opportunities and challenges to their counselors. Based on the belief of not forgetting the original intention of education and bearing in mind the mission of the times, and the analysis of the new ideas, characteristics, and behaviors of post- 00 college students, with the aim of focusing on and caring for youth, the author of the paper, as one of the college counselors in the Internet + era, facing the new opportunities and challenges brought by the post-00 college students, puts forward innovative strategies of ideological and

Keywords: internet+ era, ideological and political work, post-00 college students, new exploration

\section{ANALYSIS OF THE CHARACTERISTICS OF POST-00 COLLEGE STUDENTS}

\subsection{The Ideological and Political Situation of Post-00 College Students}

The post-00 college students are a new generation with reason and wisdom. They are more self-confident and positive, with deep love for the party, country and society, caring about national affairs, and dedicated to their motherland. Under the environment led by socialist core values, post-00 college students' political beliefs have been somehow influenced. A survey conducted by a tier-2 college shows that of all the post- 00 college students interviewed, $48 \%$ believe in communism; $39 \%$ claim that they don't have certain belief; 6\% choose Buddhism;7\% say that they haven't even thought about it. From the overall data we find that communism is still the mainstream of political beliefs among all the choices for post-00 college students. There are post- 00 s among the medical staff of the front-line epidemic prevention and control of novel corona virus-caused pneumonia, among the volunteers doing community epidemic prevention and control work in different regions and areas, and also in the battlefield of fire control. Label of "lack of political beliefs and political participation enthusiasm" on post-00s is obviously biased. Even words of responsibility, responsibility, youth, and dedication are not enough to describe those young people. Their love for the country is unbelievably deep. They are ready to sacrifice for their country whenever they are needed. However, indeed, a small number of college students don't have clear goals, firm beliefs or enough social responsibilities. Compared with the majority of post-00s who believe in Marxism and communism, a small number of them choose pragmatism or have no belief, yearning for the Buddhism-style and game life.

\subsection{The Way Post-00 College Students Acquire Knowledge}

Born in the Internet era with economy rapidly developed, post-00s' learning methods are diversified. Mu class, Weibo, WeChat, and Dou yin are all their channels of gaining knowledge and information. Online reading has become a must for them. Weibo has become an important 
medium for them to participate in politics. WeChat and QQ are widely accepted as important tools for post-00 college students to establish interpersonal relationships. People nowadays find that they can not live without Internet. Yet, network is a double-edged sword that brings both convenience and trouble.Some of the post-00s, spoiled by their parents since they were born, are impulsive and capricious. Therefore, they hate to be restrained and disciplined. If they do not use the Internet properly to acquire high-quality knowledge, they may get negative information on the Internet.

\subsection{The Mental Health of Post-00 College Students}

The social environment and family conditions of post-00 college students when they were born have provided them with a lot of possibilities to develop their potential and for them to foster more specialties. Many post-00 college students are versatile, some of whom are good at piano, chess, calligraphy and painting. They are well cultivated and more capable, so compared with the last generation, they are much more confident, sunny, and energetic. A survey conducted by a tier- 2 college shows that among all the post-00 college students interviewed, $76.5 \%$ say that they are quite positive and open-minded, easy to try and accept new things. According to a number of related surveys, every college student will face a variety of adaptability difficulties at school, such as the role change and adaptability pressures caused by the separation from their parents, the degradation of social skills caused by the overuse of mobile phone networks, and the pressure caused by the "weaning period" which requires more independence. Similarly, such adaptability problems also appear on post-00 college students, especially the pressure brought by the "psychological weaning period" on their study and life. Most post-00 college students, who used to depend on their parents to make kinds of choices in life, are now far away from their parents and have to start to live independently after entering college. Another survey on college students' mental health shows that choice disorder, sentimentality, and procrastination top all the characteristics listed. The "struggle of weaning" is quite obvious among post-00s.

\subsection{Behaviors and Life Attitude of Post-00s College Students}

Under the influence of " eight do's and eight don'ts" since childhood, and the guidance of "core values of socialism", most of them are civilized, polite and self-cultivated in daily life. Online chatting has become a mainstream among them, which replaces traditional party. In terms of entertainment, post-00 college students are willing to accept online pop culture, and online games become a daily necessity for some of them. For consumption behavior, most of them lack consumption plans, and are not sensitive of their monthly expenditure. The situation of "comfortable in the first half of the month and struggled in the second half " often occurs. Some behaviors of them may not be understood to a certain extent, but their positive attitude towards life is worthy of recognition. In the second year after the first batch of births of post-00s, China joined the WTO, on a new journey. They are the new generation shouldering the important tasks of the country, and they are also the "power generation" who make the country achieve two centenary goals. Over $90 \%$ of the post-00s agree that "success requires struggle." Many of them took Song Xi, a "national youth" among the post-90s, as their role model, and expressed their desire to learn her spirit and attitude towards life. They have relatively clear plans for their future, over $56 \%$ of whom are considering of starting-up new business on their own. They hold the firm belief that good honing gives a sharp edge to a sword and bitter cold adds keen fragrance to plum blossom. Success is not an accidental event but everyone needs continuous efforts to obtain a rich return.

\subsection{The Legal Concept of Post-00 College Students}

Legal quality is the organic unity of citizens' legal knowledge, awareness and practice ability, which is the unity of knowledge, intention and action[2].Legal knowledge includes the knowledge gained by college students in their study and practice, and their previous experience. Especially in the Internet + era, under the background of network diversification, learning good legal knowledge, having a good legal awareness, consciously abiding by legal authority, and exercising legal ability to solve problems can help you grow a talented life in college. In a survey on the view of the rule of law by post-00s, we can see that $82 \%$ of the students have some understanding of the basic knowledge of Chinese law, Yet still not enough; $96 \%$ of them can fully understand the importance of students learning legal knowledge, and have a high passion; $87.5 \%$ only remain emotionally aware of legal awareness and are lack of internalization; $41.5 \%$ said that they often use legal means to protect their rights. The improvement of legal ability helps students protect their legitimate rights and interests. In the Internet + environment, virtual temptation, campus loans, and parttime job cheating events occur frequently. In order to avoid such incidents, we must learn to use legal methods to protect ourselves. 


\section{NEW OPPORTUNITIES AND CHALLENGES BROUGHT TO THE IDEOLOGICAL AND POLITICAL WORK BY INTERNET+}

\subsection{New Opportunities Brought to the Ideological and Political Work by Internet+}

Make full use of the Internet + platform to carry out online ideological and political education. For example, counselors can use the platforms like "two micro-ends" and "troika" to make ideological and political work innovative. Many counselors nowadays set up personal WeChat public accounts to interact with their students, which is also a good way. Micro-videos related to ideological and political education posted on Dou yin are also well received by many students. Internet + platform provides good chance for counselors to have timely communication with their students online, which helps them to know more about students' daily behaviors and emotions, therefore can better solve their problems. To make full use of the Internet + platform to carry out ideological and political teaching, counselors can also add in some online games, like what is done in the course "Mental Health of College Students".

\subsection{New challenges Brought to the Ideological and Political Work by Internet+}

The Internet makes people's life and study more convenient, but also brings a certain negative impact. Facing those post-00s who just walked out of the high school life, how to guide them to screen information and make correct remarks on the online platform, how to avoid online fraud, and campus loans, and how to reduce the harm to their interpersonal relationships caused by excessive use of the Internet are all new challenges brought by the advent of the Internet to the work of counselors. Internet + brings convenience to the work of heart-to-heart conversation, but to a certain extent, it distances people on the two ends without being noticed. How to shorten the distance is also a new challenge for today's counselors. Therefore, college counselors should innovate their educational concept to motivate post-00s to take the initiative to accept and learn the ideological and political theory. They should also innovate the way of managing their students, which will be easier for post-00s to accept.

\section{NEW STRATEGIES FOR COLLEGE COUNSELORS TO CARRY OUT POST-00 COLLEGE STUDENTS' IDEOLOGICAL AND POLITICAL WORK IN THE INTERNET + ERA}

\subsection{Use Internet + Platform to Broaden New Channels for Ideological and Political Education}

Use online platform to lead students' values, conduct equal dialogues and improve the educational effect. The ideological and political departments in universities should strengthen cooperation and build a "big ideological education platform", such as link the school's public account, college's public account, and the personal public account of counselors. The college can establish an online student party member workstation, on which, for example, a student party member responsibility floor can be established to allow student party members to take the lead. At the same time, topics related to ideological and political work can be initiated on the online platform. Problems can be proposed and solved there to help students develop correct values. To build the "big ideological and political platform", we need to take multiple approaches, to seize the new position of online ideological and political education.

\subsection{Innovate the Mode of Communication, Build a New Bridge for Internet +Ideological and Political Work}

Heart-to-heart conversation is the first step for counselors to get to know their students. One of all the negative possibilities for traditional heart-to-heart conversation is that students' real thoughts may not be fully understood. Therefore, counselors should make full use of the Internet + platform to build the new communication bridge and innovate the way of work.Set up an online mailbox and allow messages left on public accounts to collect students' suggestions. To adapt to the new role of bosom friends to the students, counselors should learn to use Internet slang, pay attention to their updates on social software, and participate appropriately in the comments of students' posts online. Establish a WeChat group or QQ group to form a home-school joint force, and communicate with parents timely to be a better counselor. Counselors should take use of the Internet to be good observers, mediators, propagandists, consultants, and guides of online ideological and political education, and give full play to the radiating power and appeal of online media to become a qualified ideological and political education worker in the Internet + era . 


\subsection{Joint Efforts to Foster a Positive Mentality of College Students}

Living in a society with rapid changing and fierce competition, today's college students face a variety of psychological confusion and problems. Counselors should carry out effective psychological education in their daily ideological and political work, walk into their hearts, become their friends, and gain their full trust. For example, when a student suffers from emotional frustration, the counselor should first relate to the student, provide psychological support to help the student re-recognize the problem and divert attention, and finally achieve the goal of help him or her get rid of the emotional frustration as soon as possible. In order to alleviate the worries of the student, we can provide an online mailbox, allowing them to leave messages anonymously to help them solve their troubles. Mental health education in colleges and universities should be centered on psychological counseling on campus, with multiple participation and joint attention to form a joint force to create a sunny and positive atmosphere for college students. In daily work, "three life education" (living education, survival education, life education) should be conducted by using online software and platforms and offline materials in various forms to guide students to correctly and properly view themselves, the environment they are living in and the characteristics of the new era. What's more, teach students to treat the surroundings with a peaceful attitude and accept all the ups and downs in one's life. Don't be arrogant when it's smooth, and also not be upset when facing obstacles.

\subsection{Joint Efforts in Education to Improve the Legal Quality of Post-00 College Students}

Counselors need to enhance legal education in their daily work to improve the legal quality of college students, and bring legal education into their hearts. Typical-case education can be adopted to interpret legal cases involving college students. For example, self-love education and safety precaution education should be given to female college students, and the misguided behaviors should be found and corrected in time. For male students, conversation education receives better results. At the same time, through organizing court hearings, legal investigations, legal sketches, crosstalk, songs, drawing cartoons and other activities, students can have their legal thinking ability and practical ability enhanced, and comprehensively have their legal quality improved. Propaganda of legal education through online ideological and political education should be made to plant the seed of legal education deep into students' hearts. A linkage mechanism should be established among parents, universities and students to strengthen communication. Counselors ought to give more positive guidance in daily ideological and political work, create a good atmosphere of legal awareness, and teach students to abide by and use the law, being an active practitioner of national legal construction.

\subsection{Strengthen Learning and Innovate Ideas to Improve the Comprehensive Quality of Counselors}

There is an old saying in China that if you want the train to run fast, you'll need a powerful locomotive to lead. It is far from being satisfactory if counselors continue dealing with the new problems or old problems but with new forms based on subjective imagination formed by previous experience when there are post-00 college students, the new generation, standing in front of us. The newborn Internet+ platform has innovated the channels for ideological and political education work. At the same time, we need to be clear that it puts forward higher requirements for college counselors today in terms of the comprehensive quality. To keep up with the development of the times and receive a good result of ideological and political education work on post- 00 college students in the new period, we must constantly "charge". As one of the counselors in the new era, in addition to strengthening the study of multidisciplinary theoretical knowledge, establishing a new perspective on teachers and students, actively exploring new responsibilities and roles in the construction of students' Internet + life, mastering the necessary Internet knowledge and skills, with strong information discrimination awareness, information analysis ability and good information ethics, giving full play to the advantages of the network, building a management system that combines the inside and outside of the network and interacts online and offline are also necessary. Counselors should not only participate in ideological and political education training and seminars arranged by the school, but also actively communicate and discuss with other peers from different levels and regions in colleges and universities to enrich their work experience whenever there is a chance. Under the background of economic globalization, counselors should also be proficient in English, so that they can have students willingly convinced when carrying out the education work, and benefit more from the foreign universities and colleges of the advanced management experience.

\section{CONCLUSION}

The era makes youth, and youth makes the era. Contemporary college students are at the right time, and completely able to take over the baton of the cause of socialism with Chinese characteristics. In practice, counselors should take "everything for students, for students' everything, and for all the students" as the basis of work. Counselors should strengthen the study of political theory in daily work, summarize and reflect in practice, and, dealing with the new generation with new problems, new ideas, and new characteristics, advance 
with the times. Only by winning young people can we handle the challenges and win the future.

\section{REFERENCES}

[1] Ministry of Education. Regulations on the Construction of Counselors in Higher Education Institutions (Decree of the Ministry of Education of the People's Republic of China, No. 43 of 2017) [Z].

[2] Gong Pixiang. "Theoretical Logic of Legal Modernization", China University of Political Science and Law Press, 1999 edition, page 68. 